\section{A Gulliverian} orthogonal planning: a modular reading of Classical Thourioi

\section{Renan Falcheti Peixoto [*;**;***]}

[*] Double PhD candidate at the Museum of Archaeology and Ethnology of the University of São Paulo (MAEUSP), São Paulo (SP), Brazil. falcheti.peixoto@usp.br

[**] Department of History and Cultures of the University of Bologna (DiSCi-UNIBO), Bologna, Italy.

ORCID: https://orcid.org/0000-0001-5347-526X

[***] Scholarships of the FAPESP - São Paulo Research Foundation (grant numbers 18/06265-0 and 19/24957-9). M.A. in Archaeology (MAE-USP-2017), sponsored by FAPESP (14/06260-7 and 16/00914-0).

\section{Maria Beatriz Borba Florenzano [ $\left.{ }^{\mathrm{x}}\right]$}

${ }^{[}{ }^{\mathrm{x}}$ Full Professor of Classical Archaeology (MAE-USP). General coordinator of the Laboratory for the Study of the Ancient City (Labeca-MAE-USP).

São Paulo (SP), Brazil. florenza@usp.br

ORCID: https://orcid.org/0000-0002-4350-2372

\begin{abstract}
This paper uses the Gulliverian metaphor to examine the organization of a well-known Classical orthogonal planning in Magna Graecia, south Italy. After observing the relationship between the elements of the urban grid of Thourioi, we will propose the application of a modular unit formed by the sum of ten Attic feet by the geometer of its urban plan. According to our main argument here, this module orientated the land-measurement of Thourioi by co-measuring the width of ithe roadway network and width/length of blocks, lots, and "major rectangles". Furthermore, certain alignments in its planning are physically established, as it will be demonstrated in the case of its major roads. Thourioi calls forth through its compositional structure of older formulas a wider horizon of orthogonal planning tradition, an ancient scansion rhythm reified in archaeological patterns of many Greek Western foundations since the VIII century BC.
\end{abstract}

Keywords: Thourioi; Ancient urban planning; Orthogonal technique.

\section{Um planejamento ortogonal guliveriano: uma leitura modular da Túrio do período clássico}

Resumo: O presente artigo trabalha com a metáfora de Gulliver para examinar a organização de um célebre planejamento ortogonal na Magna Grécia, sul da Itália. Depois de observar as relações entre os elementos urbanos da grade de Túrio, proporemos uma unidade modular formada pela soma de dez pés áticos aplicada pelo geômetra de seu plano urbano. De acordo com nosso principal argumento aqui, este módulo orientou a medição do terreno em Túrio ao dimensionar a largura da malha viária e largura/comprimento dos blocos, lotes, e módulos quase quadrangulares. Ademais, certos alinhamentos de seu planejamento são estabelecidos fisicamente, como será demonstrado no caso de suas principais estradas. Túrio traz à tona, por meio de sua estrutura composicional de velhas fórmulas, um amplo horizonte do planejamento antigo, um ritmo de escansão retificado nos padrões arqueológicos de muitas fundações gregas do Ocidente desde o século VIII a.C.

Palavras-chave: Túrio; Urbanismo antigo; Técnica urbana ortogonal. 


\section{The Gulliverian metaphor}

T $\mathrm{n}$ the first adventure of the sea explorer Gulliver in John Swift's Gulliver's travels ([1726] 2004), the hero stops in the little community of Lilliput, a tiny island populated by Ltiny inhabitants six inches high. The engineering and sagacity of that people is described in an almost ethnographic style, as in others Gulliverian journeys in fantastic countries such as Brobdingnag, Laputa, Balnibarbi, Luggnagg, Glubbdubdrib, Japan, and Houyhnhnms. In Lilliput, practical matters have to be addressed all the time and Swift gives to the reader plenty information regarding the resourcefulness of the Lilliputians in coming to grips with them.

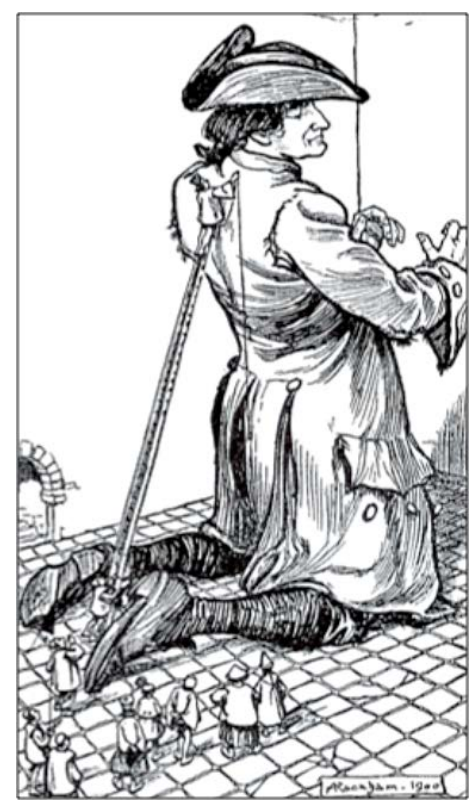

Figure 1. Gulliver being measured

(Swift, 2004, p. 79).

The facts which mostly interest us here are those regarding the management of the strange giant found on the sea coast by the Lilliputians: Gulliver was tied up, carried to the country, in short, monitored and supplied with massive amount of food in the length of his stay there. The great hero puts to the test all geometrical knowledge of the Lilliputians. We focus here on the events taken place during the renewal of Gulliver's worn clothes, a rich literary engineering by itself. How could this enormous task had been accomplished by minuscule seamstresses (Figure 1)? Gulliver himself told us that

The sempstresses took my measure as I lay on the ground, one standing at my neck and another at my mid-leg, with a strong cord extended that each held by the end, 
while the third measured the length of the cord with a rule of an inch long. Then they measured my right thumb, and desired no more, for, by a mathematical computation, that twice round the thumb is once round the wrist, and so on to the neck and the waist [...] Three hundred tailors were employed in the same manner to make me clothes, but they had another contrivance for taking my measure: I kneeled down, and they raised a ladder from the ground to my neck; upon this ladder one of them mounted, and let fall a plumb-line from my collar to the floor, which just answered the length of my coat [...] (Swift, 2004, p. 78).

The Gulliverian metaphor was envisaged to describe the spatial organization process that orthogonal Greek cities of Classical times like Thourioi have structured over time In the Swift's story, the seamstresses of Lilliput obtained the diameter measures of the waist, the neck, and the fist of Gulliver by putting only one retracted rope around his thumb. According to this notion of equivalence, comparable with Vitruvian Man, two turnings around the thumb equate to one in the fist (1:2); two turnings in the fist equate to one in the neck (1:2); and two turnings in the neck equate to one in the waist (also l:2). In this way, the following whole-number ratios of single body parts measured against the thumb are envisioned from this sense of proportion: thumb/waist: 1:8; thumb/neck: 1:4; thumb/fist: 1:2.

As in this episode of Lilliputian seamstresses, we will observe in this paper that there is the same principle when it comes to the intricate relation between the metrological values employed in the orthogonal planning of Thourioi. This means that taking the width or the length of one of its urban element as blocks, streets, or house lots is also taking the proportion of another. Therefore, the metaphor of a practice of measuring width, length, and height of a human body through its single parts can be followed in our case. That is the meaning carried over by the metaphor (from the Greek metaphérō, "to carry over") that will be explored in a city planning hereafter.

\section{A Classical orthogonal planning in Magna Graecia}

Thourioi was an Athenian Classical foundation in the Gulf of Taranto, facing the Ionian Sea between the rivers Sybaris and Coscille in the modern region of Calabria, southern Italy. According to the literary testimony of the Greek historian Diodorus Siculus (1946, XII, X, $6)$, its foundation was established in 444-443 BC. The city was settled on the same spot of

'Another Gulliver's adventure, among the Laputans, is the departure point of a thought-provoking idea about the metaphorical meaning of the division of Megara Hyblaea's space and the division of the sacrificial meat in ancient Greek thought (Svenbro, 1982, p. 953). 
Sybaris, the far larger city of the Archaic period, whose complete destruction and abandonment have been brought about in 510 BC, after a war against Crotone in this same year. This historical event was confirmed independently by an archaeological terminus ante quem made up by a sterile stratigraphic level of alluvium concealing the period in Stombi, the northern archaeological area plenty of structures of the Archaic times.

The events related to the war as well as, succeeding it, the sending of an embassy to Athens seeking help to the foundation of a new settlement on the same spot, the urban implementation of Thourioi, the composition and origin of its settlers, the intestinal fights between new and former inhabitants that followed, and, finally, the establishment of a constitution in the aftermath of civil conflict are all described in the preserved books of Library of history (Diodorus Siculus, 1946, XII, X). Even though our focus in this article is not written sources, ${ }^{2}$ the unique planning description of Thourioi offered by the late Greek historian who lived in the Roman period well deserves to be quoted here:

They divided the city lengthwise by four streets [plateiai], the first of which they named Heracleia, the second Aphrodisia, the third Olympias, and the fourth Dionysias, and breadthwise they divided it by three streets [plateiai], of which the first was named Heroa, the second Thuria, and the last Thurina. And since the quarters formed by these streets were filled with dwellings, the construction of the city appeared to be good ${ }^{3}$ (Diodorus Siculus, 1946, XII, 10, 7).

Further archaeological works have back up part of this Diodorian description of the Classical grid situated under the Roman stratigraphic level. Field campaigns conducted in the area during the years between 1969 and 1974, coordinated by the Italian archaeologist Pier Giovanni Guzzo and sponsored by Cassa del Mezzogiorno, have opened huge excavation sites known since then as Parco del Cavallo, Prolungamento Strada, Casa Bianca (cf. Fig. 3) and Stombi. The archaeological reports of these field works have been published in five supplementary volumes in the journal Notizie degli Scavi during the next twenty years following the last work season.

Combining the pieces of archaeological information with the written account, we have at Parco del Cavallo an orthogonal crossing of two major roads, out of seven mentioned in Diodorus' text, plateia A in N-S direction and plateia B in E-W direction. At Prolungamento

${ }^{2}$ This explains in part why we maintain in this paper silence about the historiographical strand of tradition associating the city with Hippodamus of Miletus, the "father" of town planning. Diodorus does not mention this at all. Moreover, the father's baby has been thrown out with the bathwater of revolutionary inventions, as we shall try to show.

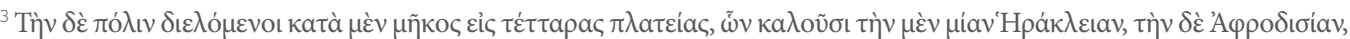

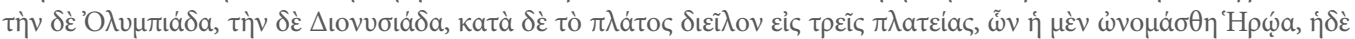

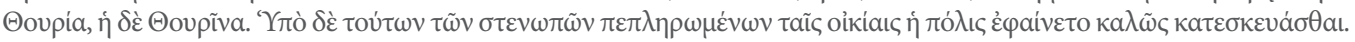


Strada, another street running N-S was identified. This street network gives us an overall picture of the urban scheme that, once having the width and length measurements of the elements converted to the standard foot that specialists agreed upon, the Attic's (29,5 centimeters, or 0,295 meters, approximately), can be presented according to Figure 2. The measures below concern the width of streets, the axial distance between plateiai A and B (1000 feet), and the width and length of blocks (not expressed in the drawing).

Figure 2 - Projection of the blocks from the excavated street crossing in Parco del Cavallo. Source: modified from Greco (1999, p. 417, Fig. 72).

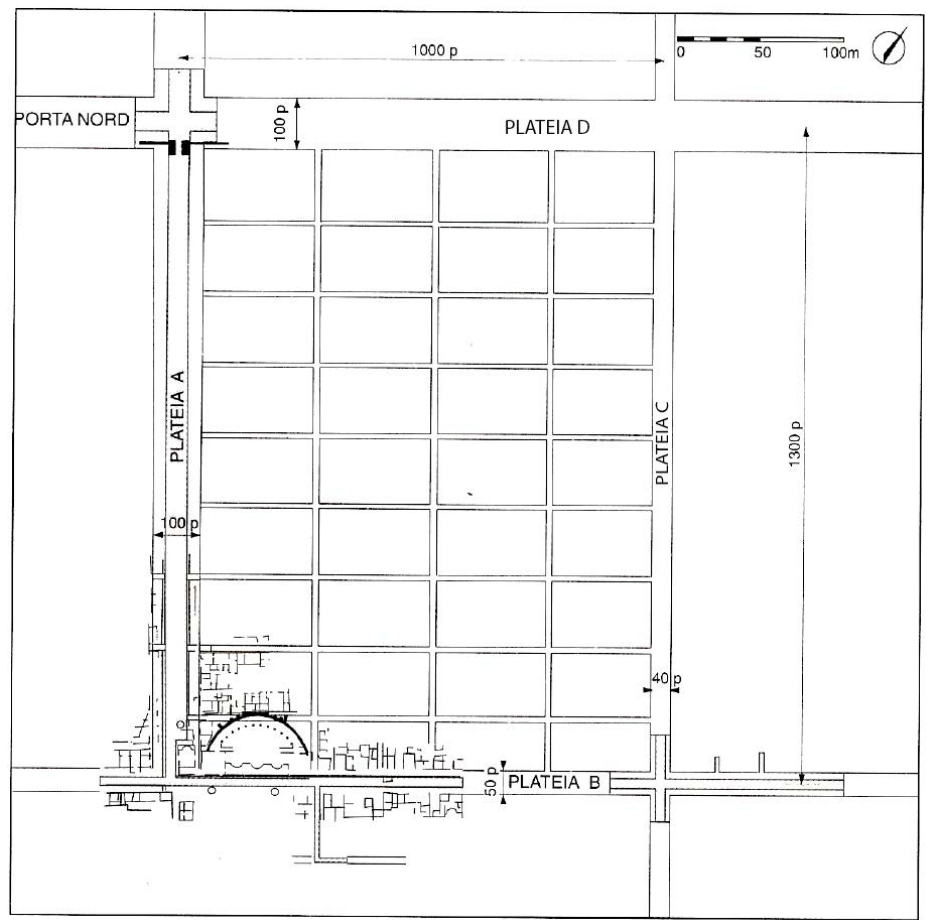

Taking into consideration the measures identified, it is possible to draw a hypothetical urban plan reconstruction based on the projection of several replicas of the "major

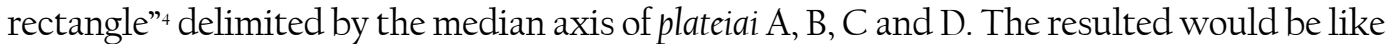
the urban fabric imagined by Emanuele Greco and Silvana Luppino, the Italian archaeologists responsible for the field seasons in Thourioi between 1992-1999 (Figure 3). In the next section, we shall come to understand better this large piece of the urban scheme.

${ }^{4}$ This term is taken from both Cahill (2002, p. 5, 22) and Shipley (2005, p. 353) 


\section{Figuring out a large and key element of planning}

Focusing on this large rectangle, we can observe the stages of planning of the Classical grid as reconstructed by the specialized bibliography after the publication of the first results. Doing so, we will pave the way for finding a modular unit underlying the calculation of some elements of the urban fabric. The aim of this section is to draw attention to archaeological data and highlight the relationship between the elements of planning which have been pointed out in summaries written by some leading Italian archaeologists over the last decades (Guzzo, 1973; 1974; 1981; Belvedere, 1986; Greco, 1999). Below, we present a model built with a three-dimension software tool (SktechUp) that allows in an easy and precise way to set up visually the geometrical divisions proposed by the major interpretations, which are anchored on the evidences regarding mostly the archeological areas of Parco del Cavallo and Prolungamento Strada.

Figure 3 - "Major rectangle" indicated by the colored form within the reconstructed urban Classical grid of Thourioi. Source: modified from Greco; Luppino (1999, p. 154, Fig. 27).

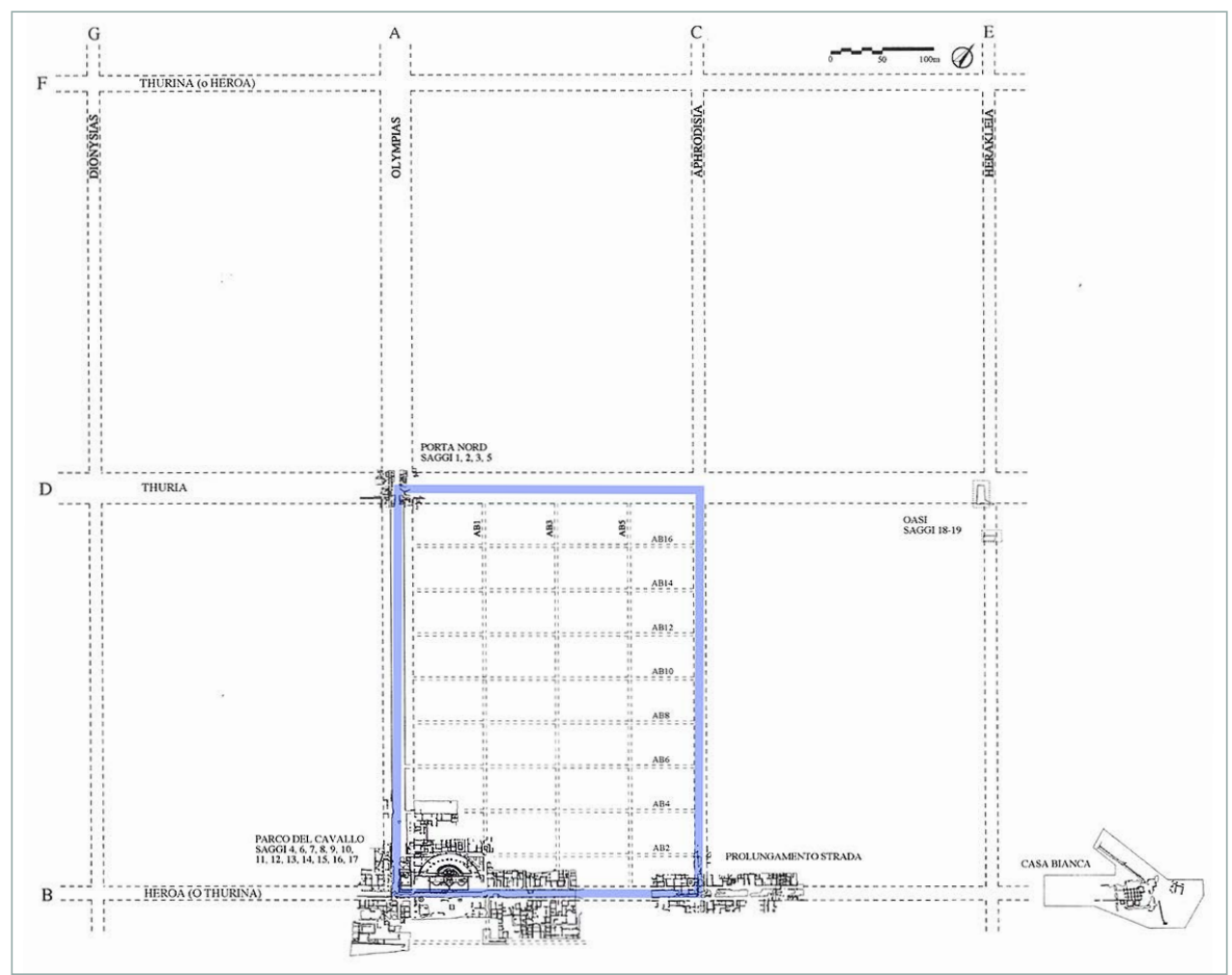


The "major rectangle" of 295 by $390 \mathrm{~m}$ is measured considering the axial distances of the four plateiai that delimit its sides. The main hypothesis of urban reconstruction of Thurioi is based on a projection of several modules like this one drawing on the ground an urban fabric of 700,000 m² (70 hectares) (Cerchiai; Jannelli; Longo, 2004, p. 120). Furthermore, these large rectangles would triggered the subsequent divisions of other urban features of the planning, i.e., stenopoi (narrow streets), blocks and private lots, ${ }^{5}$ within its huge framework.

Figure 4 - Sequence of division in Parco del Cavallo. a) "Major rectangle" drew on with the median axis of plateiai A, B, C and D; b) Width measurement of the plateia in dashed lines; c) Demarcation of the first block and the stenopoi metrically elaborated from the data reported; d) Ideal projection from the initial distances offered by the first of all blocks. Drawing: authors.
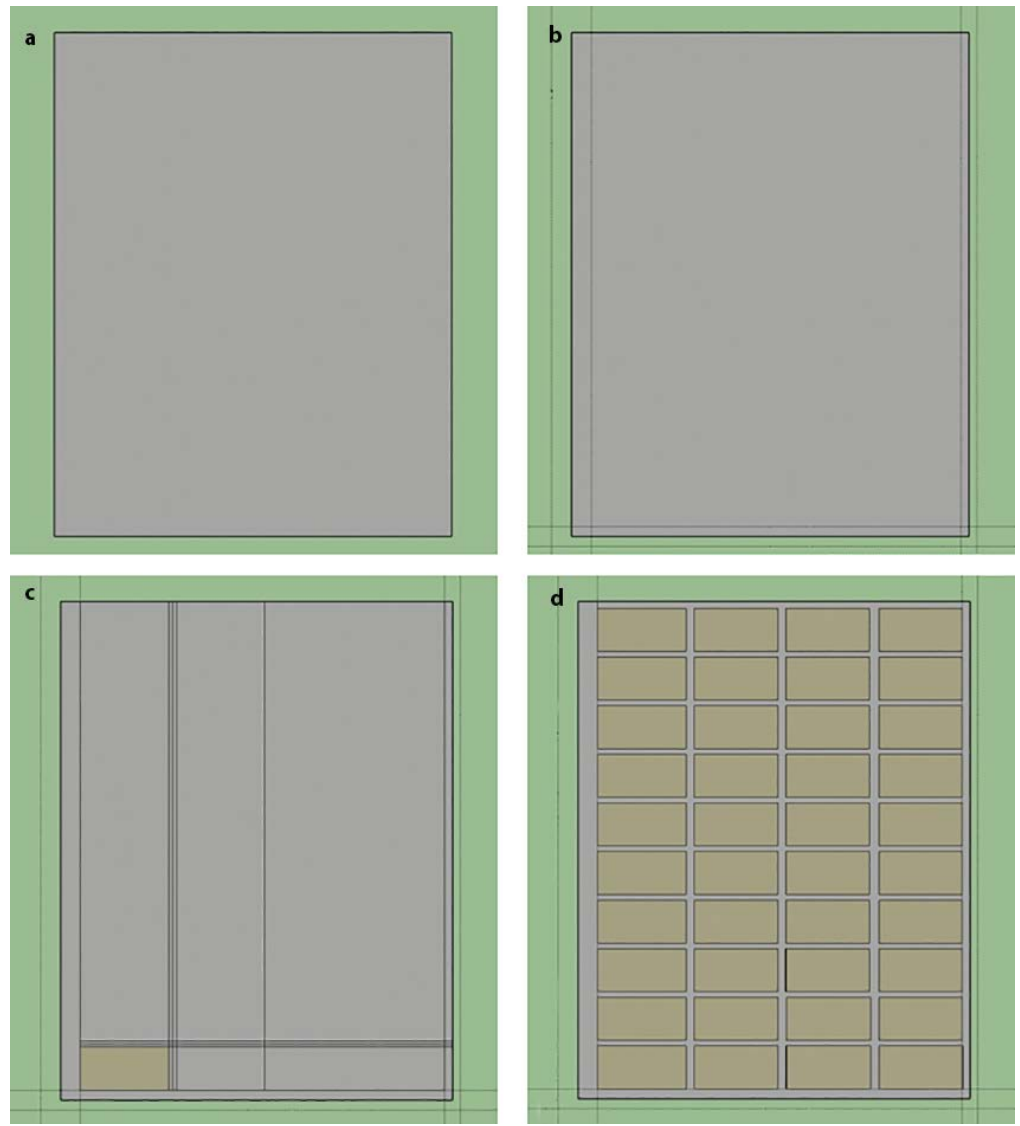

${ }^{5}$ For our purpose here lots, private houses, and house lots are all employed interchangeably. 
Initially, from the perimeters of a large rectangle overlapping the axial lines of the arterial roads, it would be possible to establish the width of each plateia, in both sides (Figure 3, in blueberry). From this large rectangle Oscar Belvedere (1986, p. 11-12, 14) follows the sequence of mental diairesis, "division," that the planner would performed in the space to accomplish his task. He used the measures offered by the planimetric maps given in Sibari IV (Figure 29l) and we like to detail his proposal, even though nowadays the sketches are in some regards a bit outdated. ${ }^{6}$

From this larger rectangle (Figure 4, a) of approximately 295,5 m wide by $380 \mathrm{~m}$ long, half the width of each plateia is subtracted in both sides from the axis (dashed lines in Figure 4 , b). Next, and particularly important to us here, the urban blocks within which lie the house lots are determined by replicating blocks measuring 70,5 by $35 \mathrm{~m}$. By way of example, we demonstrate one of these blocks in aspargos color (Figure $4, \mathrm{c}$ ). The stenopoi would be extracted from its axis after this process of block scansion (Figure 4, d). At length, and based in the partial widths of the recognized stenopoi, ${ }^{7}$ we have the appearance of a grid form, or, as this kind of layout is usually called in urbanism manuals, a truly "chessboard" scheme.

Absent from these drawings, as we can notice, are the spaces intended to the oikopeda, the individual urban house lot where it is allowed to build a private house. It is worthwhile saying that the difficulty in detailing these structures is largely due to the closeness of the water table to the surface and the marshy ground which make hard the task for archaeologists digging on the area. Beyond that, the Classical settlement does not correspond to the last phase of occupation of that area. Roman urban structures were over the Greek site in the same way as the Athenian foundation superposed Sybaris. It comes as no surprise to find urban agglomerate with extensive chronologies of human occupation as this one has been called "the messy empirical reality" (Smith, 2007, p. 41) of researchers.

Notwithstanding the uncertainty of evidence and the low visibility of house structures, we gathered up some data regarding these structures as to compare it with the evidence provided by the aforementioned archaeologists. ${ }^{8}$ The main idea in establishing this methodological

\footnotetext{
${ }^{6}$ For instance, the north side of the "major rectangle," corresponding to plateia D, was not drew on the Figure, since the precise measurement of this road, at this juncture of the seventies and eighties, was not obtained. Today we know that it had measured almost $30 \mathrm{~m}$, the same value of the revised measure of plateia B, that also has to be updated. However, these new measures do not hinder the interpretation put forwarded here.

7 It is known now that the second stenopos running N-S (AB 3) lies 70 m east from the first stenopoi N-S (AB 1), because we understand, following Belvedere (1986, p. 12), that Roman structures 48 and 49 in Parco del Cavallo are over an obliterate stenopos. Stenopos AB 1 is 70,5 m distant from the eastern border of plateia A. We follow here the labels of stenopoi in the map offered by Greco and Luppino (1999, p. 154, Fig. 10), here Figure 3, in order to standardize the nomenclature. ${ }^{8}$ Examples of this are the superposition of some house structures like structure number $2 \mathrm{NE}$ and 58 and $76 \mathrm{~S}$ in Parco del Cavallo and traces of an edification in $36 \mathrm{~N}$ Prolungamento Strada. This last structure seems aligned with plateiai B and $\mathrm{G}$, both paved at the end of the $\mathrm{V}$ century and early IV BC, contemporaneously, therefore, to the period assigned to
} 
procedure is to point out that the houses and the lot area in Thourioi's plan did not received so far the appropriated attention it deserves. We argue that the urban house lot was - and still is - regarded as of less importance vis-à-vis other hierarchically-organized elements of its plan. Even if the data concerning the Classical structure is hard to take, we will use the scanty information we have to guide us in our framing of an orthogonal planning that takes into account all its pieces, attempting to characterize the internal dynamics of the planning process. To establish the underlying relationship between each element of Thurioi's urban layout, we have first to decompose analytically the constitutive elements of the orthogonal scheme. Doing so, it is as if we had dismantled its formal structure, anatomize the body of the city so to speak, in order to fit the pieces together and make sense of the whole process.

\section{The urban house lot in Thourioi's planning}

[...] a wooden jigsaw puzzle [...] is [...] a pattern, that is to say a form, a structure: the element's existence does not precede the existence of the whole, it comes neither before nor after it [...] That means that you can look at a piece of a puzzle for three whole days [...] and be no further on than when you started. [...] But as soon as you have succeeded [...] in fitting it into one of its neighbours, the piece disappears, ceases to exist as a piece. (Perec, 2008, p. 189).

Emanuele Greco (1999, p. 416-417), the renowned Italian archaeologist former director of the Scuola Archeologica di Atene (SAIA), was the first to provide measures of the houses of Thourioi in a working hypothesis of its urban planning. Notwithstanding the slightly different measures provided by Greco, by and large the sequence of his proposal remains similar to what was advanced before: a "major rectangle," cut by transversal and perpendiculars stenopoi which take a portion of space to delineate blocks. Next, zooming in on the block's level, each block is subdivided into lots. Greco considers that one block 74 by $35-37 \mathrm{~m}$ wide would be halved by a sewer $1,80 \mathrm{~m}$ wide, forming two square blocks of $37 \mathrm{~m}$ (Figure 5). In the end, there are left two square blocks with sides of $37 \mathrm{~m}$, “[...] pari, con ogni verosimiglianza, a due abitazioni a pianta quadrata, con un lato di m 17-18[...]”. (Greco, 1999, p. 417). ${ }^{9}$

its urban planning (Guzzo, 1973, p. 291; 1981, p. 18; for information about structures 76 S, 58 NE and 36 N, cf. Sibari III, p. 285287; Sibari IV, p. 190-191, 194-196; Sibari V. p. 357 sgg.).

9 "[...] equal, with all likelihood, to two houses with a square plan, with a side of 17-18 m [...]". 
Figure 5 - Hypothesis on the division of the urban block in Thourioi. Drawing: authors.

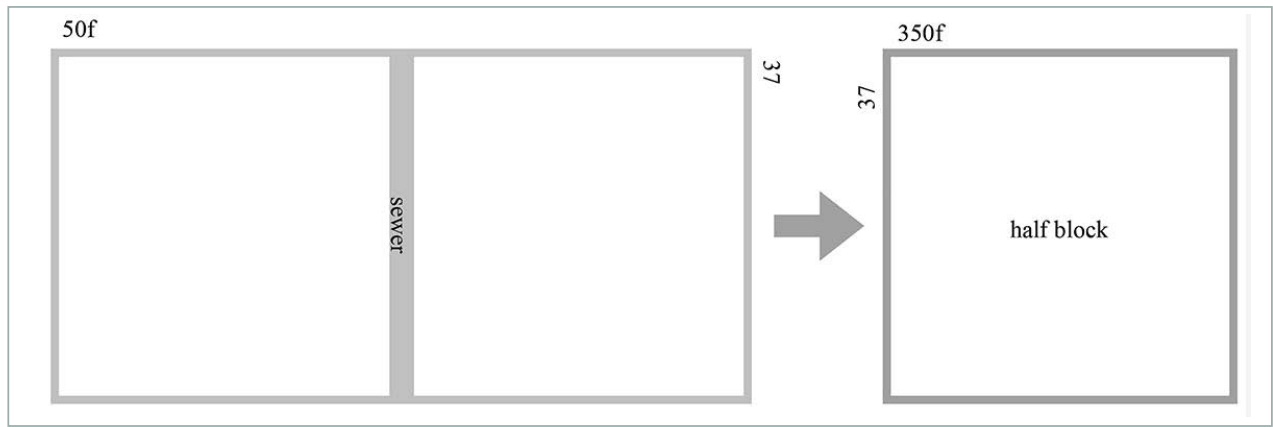

Just putting these numbers on paper to realize two squares $17-18 \mathrm{~m}$ of side corresponding to the lot do not fill a square surface of 37 by $37 \mathrm{~m}$ (Figure 6, a). Instead, assuming four houses of $17 \mathrm{~m}$ plus partition walls of $1 \mathrm{~m}$ wide, we can fill all the area (Figure 6, b). Probably that was the author's intention, after all, in an article wrote by Lo Sardo (1999, p. 94) in the same book where Greco published his aforementioned article, we can find a reference to 4 houses with square plan of $17-18 \mathrm{~m}$.

Figure 6 - Hypotheses on the private lot area in Thourioi. Drawing: authors.

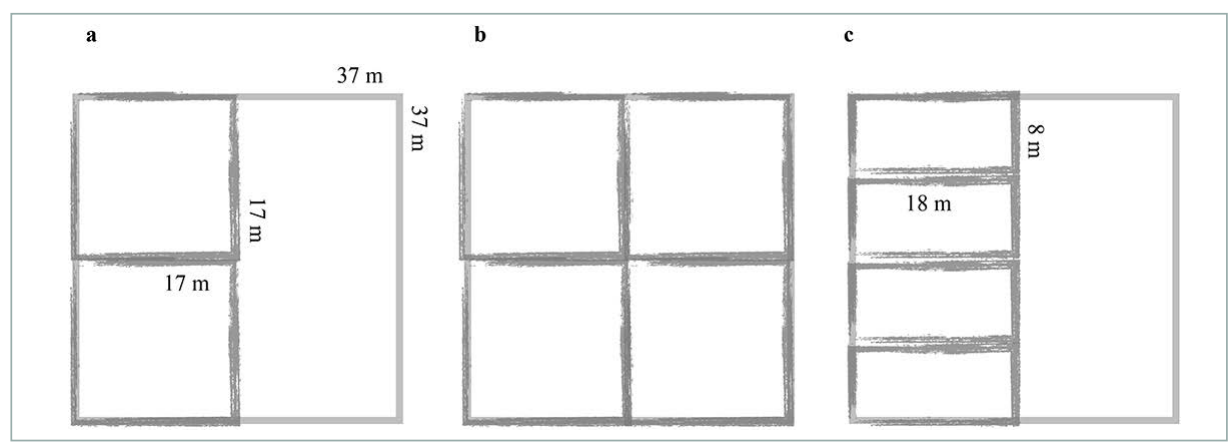

We would maintain this reasoning, even if Greco (2009) published another paper ten years later in which he putted forward a new hypothesis concerning the measurements of the house lot. The core of his argument concerning the hierarchical organization of large rectangle, major roads, and blocks remains, with minor modifications. However, this time the surface area of a half block of $37 \times 37 \mathrm{~m}$ would be filled by four rectangular houses $18 \mathrm{~m}$ wide and $8 \mathrm{~m}$ long, which does not make any sense (Figure 5, c) (Greco, 2009, p. 114). 
Unless each lot would have some kind of non-built empty space of the same size in front of house building, maybe a garden (kēpos), we still have the same problem previously mentioned: the total area is not covered and the author did not give any clue about built and non-built spaces mirroring each other. As this is probably not the case, we can add up to each block a total of 8 lots, 2 in its width and 4 in its length (Table l, Figure 5, b, it is worth remembering that the Figure represents the half block's length).

Table 1 - Number of lots per block in Thourioi

\begin{tabular}{|c|c|c|}
\hline BLOCK & BLOCK & TOTAL \\
\hline 1 & WIDTH/LENGTH & 8 lots \\
\hline
\end{tabular}

It may be noted that these incongruences bring on severe headaches in a careful reading. In fact, we have not found in published archaeological reports and in the specialized bibliography what structures Greco had in mind to make his arrangement. We shall mention this because an archaeological source review is necessary to archaeology made by "digging up" published field reports in library's shelves. Working with Classical Archaeology in the other side of the Atlantic, a peripheral position compared to European academic centers, make us Brazilian Classical archaeologists dependent of scientific publications in terms of access to reliable empirical data. We feel obliged to say before proceeding that as members of the Laboratory for the Study of the Ancient City (Labeca-MAE-USP) over the last years we could profit from the material benefits provided by a solid educational institution. Consequently, we do not have a ground proof on this specific subject or field experience to learn what reports do not mention. Be that as it may, we would like to integrate in the next section the measures of the urban house lot, even if uncertainty surrounds it. It is not justifiable to approach it only in the final moment of the urban planning process, being it a key element of structural organization of the layout (Florenzano, 2014 , p. 77-78). In a word, the lot is a piece needed for solving the puzzle of the Greek orthogonal layout and building up a complete picture of the planning process.

\section{A modular reading}

We introduce in this section a modular reading of Thourio's planning, departing ourselves from the hypotheses which have been proposed by important archaeologists over the last decades. A module for us is not an indivisible unit (sensu Tréziny, 1999: 173). Rather, it is a divisible and flexible measure spinning a complex web of relations within the urban fabric. 
There is no plausible reason for associating module with non-fractionability in Greek town planning or temple building..$^{10}$ In light of such reasoning, we propose first there is a 1:2 relationship between the N-S and E-W stenopoi that corresponds both to the proportion width/ length of the block and width of block/number of houses aligned in its width. Adhering to the idea that the planning process begins with the definition of median axis of arterial roads, in order to demarcate the large rectangle, we go further to show that the geometer's technique made use of a module formed by the sum of 10 Attic feet. This module patterns decimal relations of several elements of the urban form, building up links from the smaller to the larger.

Even although that formula was used for different organizational principles in Thourioi's planning, as we shall come to understand, there is the instantiation of a material pattern of an old orthogonal formula well diffused in Greek Western foundations scattered in the Mediterranean basin since the VIII century BC. As Boyd and Jameson (1981, p. 333) have highlighted, the integral ratio of $1: 2$ between block's sides is a common pattern linked to the number of houses within the block and its traditional measures:

There is a controlling factor in every instance of an orthogonal plan, of course, and this is the size of the individual houses to be contained within the insulae [blocks]. Whatever approach is used for establishing the main lines of an urban plan, strips or squares, the resulting insulae must accommodate the houses. Greek houses in planned cities tend to be square, or nearly so, measuring about 50 or 60 feet on a side.

Our working hypothesis predicts the urban fabric is woven not only with a series of arithmetical ratio of 1:2 but also with a module that engenders a series of decimal proportions between its components, a cast against the elements have to be measured against. The urban form establishes a commensuration between the parts to one another and to the whole form. The modular unit suggested is equal to $2,95 \mathrm{~m}$, result of the sum of 10 Attic feet. The plateiai, stenopoi, larger rectangle, blocks, and house lots are measured against this unit. By means of this module, the ensemble of the pieces are organized. Each measure predicts the other because they are all effectively tied together (which is to say commensuration, symmetria). The oikopeda square surface area, for example, would have 6 modules in its side (2,95 x 6 = $17,7 \mathrm{~m}$ ) and a surface area of $295 \mathrm{~m}^{2}$ (Figure 7). The measure of $17,7 \mathrm{~m}$ is close to the $17,2 \mathrm{~m}$ of Olynthus' standard-lot and could incorporate a variation margin despite the high value of partition walls (Cahill, 2002, p. 74).

${ }^{10}$ As a matter of fact, the fractioning of a module is a common practice among Greek temple builders, as Wilson Jones (2001, p. 681) has suggested in his analyses of Doric temple façades of classical period: "Any mathematical strategy is only as flexible as designers allow it to be". 
Figure 7 - A modular reading. Drawing: authors.

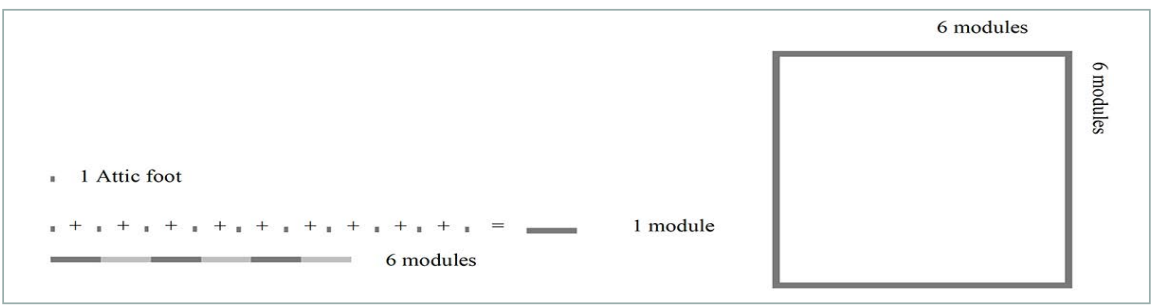

The measure of the lot is taken based on the modular commensuration with the measure of the block, as the measure of the block is taken based on the width of streets. Likewise, the width of streets is taken based on the modular commensuration between the width and length of the large rectangle. In Attic feet: 1 hundred feet (10 modules) corresponds to the width of plateia A (around 29,5 m) (2,95 x 10); 1000 feet, or 100 modules (295 m) is the width of the "major rectangle" in Parco del Cavallo. The block has 120 feet by 240 feet, i.e. 12 modules by 24 modules or whole-number ratio of $1: 2$ between its width and length. The number of predicted blocks aligned in the length of the large rectangle is 10 , number that if multiplied by the 4 blocks predicted in the width direction adds up a total of 40 blocks inside the large rectangle surface area (Table 2; cf. Figure 4, d).

Table 2 - Number of predicted blocks per large rectangle in Thourioi

\begin{tabular}{|c|c|c|}
\hline LARGE RECTANGLE & $\begin{array}{c}\text { BLOCK } \\
\text { LENGTH/WIDTH }\end{array}$ & TOTAL \\
\hline 1 & $10 \times 4$ & 40 blocks \\
\hline
\end{tabular}

Not only plateia A, but all the roadway network fits in this module unit. Likewise plateia A, plateia B and plateia D have around 30 m including sidewalks: thus, 10 modules both. ${ }^{.1}$ Plateia C has $12 \mathrm{~m}$ of paved street plus $6 \mathrm{~m}$ of sidewalks: 6 modules, the same valuer of the side of the square urban house lot, as we have seen. The first N-S stenopos ( $\mathrm{ABl}$ ), parallel to plateia A, has about 2,90 m of width of paved street plus $4 \mathrm{~m}$ of sidewalk, totalizing almost $7 \mathrm{~m}$ of width: 2,4 modules. ${ }^{12}$ This is interesting, because 2,4 modules are in a decimal relation to the length of the block of 24 modules. The same relation between sides of blocks and $\mathrm{N}-\mathrm{S}$ stenopos could be observed in the other side. For instance, stenopos E-W AB2,

\footnotetext{
"Archaeological works in Casa Bianca have revealed that plateia B had shortened by half during the Roman period (cf. Greco; Luppino et al., 2003, p. 101; Greco; Vitti; Voza, 2011, p. 318). Hence, it is necessary to update the measure of 50 Attic feet given previously by archaeological reports.

${ }^{12}$ Cf. Sibari Il, p. 437-438 on the roadway and sidewalk of stenopos AB1.
} 
perpendicular to plateia A, lies 3,40 m wide and do not have sidewalks, a close value compared others E-W stenopoi identified (AB4 and AB6) and, therefore, could be more or less 1,2 module, which is in another decimal relation with the width of the block (Table 3).13

Table 3 - Measures of the urban components of Thourioi and arithmetical relations between them

\begin{tabular}{|c|c|c|c|c|}
\hline $\begin{array}{l}\text { URBAN } \\
\text { ELEMENT }\end{array}$ & IN METER & ATTIC FEET & $\begin{array}{l}\text { IN MODULE } \\
\text { (10 ATTIC } \\
\text { FEET EACH) }\end{array}$ & $\begin{array}{c}\text { FRACTION AND RATIO BETWEEN } \\
\text { THE URBAN ELEMENT }\end{array}$ \\
\hline $\begin{array}{l}\text { Large } \\
\text { rectangle }\end{array}$ & $295 \times 390 \mathrm{~m}$ & $1000 \times 1300$ & $100 \times 130$ & 10 times the width of the plateiai A, B, and D \\
\hline Blocks* & $\begin{array}{l}35 \times 70,5 \\
36,8 x ? \mathrm{~m} \\
39 x ? \mathrm{~m}\end{array}$ & $\approx 120 \times 240$ & $12 \times 24$ & $\begin{array}{l}10: 1 \text { between its width and width of stenopoi E-W } \\
10: 1 \text { between its length and width of stenopoi } \mathrm{N}-\mathrm{S} \\
1: 2 \text { between its width and length }\end{array}$ \\
\hline Plateia A & $29,5 \mathrm{~m}$ & 100 & 10 & $1 / 10$ of the width of the large rectangle \\
\hline Plateia B & $29,5 \mathrm{~m}$ & 100 & 10 & $1 / 10$ of the width of the large rectangle \\
\hline Plateia C & $18 \mathrm{~m}$ & $\approx 60$ & $\approx 6$ & $\begin{array}{l}1: 1 \text { between its width and the lot square size } \\
2 / 5 \text { of the width of plateiai } A \text { and } B\end{array}$ \\
\hline Plateia $D$ & $29,5 \mathrm{~m}$ & 100 & 10 & $1: 1$ of the plateiai A and B \\
\hline $\begin{array}{l}\text { Stenopoi } \\
\text { E-W }\end{array}$ & $\begin{array}{l}\mathrm{AB} 23,40 \mathrm{~m} \\
\mathrm{AB} 4: 3,20 \mathrm{~m} \\
\mathrm{AB} 6: 3,40 \mathrm{~m}\end{array}$ & $\approx 12$ & $\approx 1,2$ & $\begin{array}{l}1 / 10 \text { of the width of the block and } 1: 2 \text { of the } \\
\text { width of the stenopos } N-S\end{array}$ \\
\hline $\begin{array}{l}\text { Stenopos } \\
\text { N-S }\end{array}$ & $\mathrm{AB} 1: 6,90 \mathrm{~m}$ & $\approx 24$ & $\approx 2,4$ & $\begin{array}{l}\text { 1/10 of the length of the block } \\
2: 1 \text { of the width of the stenopoi E-W }\end{array}$ \\
\hline Lot & $17,7 \times 17,7 \mathrm{~m}$ & $60 \times 60$ & $6 \times 6$ & $\begin{array}{l}1: 1 \text { between its size and width of plateia } C \\
2 / 5 \text { of the width of plateiai } A \text { and } B\end{array}$ \\
\hline
\end{tabular}

* From south to north, first row to the left (at the eastern margin of plateia A and northern margin of plateia B.

Source: Sibari II, p. 437-438; Sibari V. p. 304; Greco (1999, p. 416-417); Greco; Luppino et al. (2003, p. 101-102); Greco; Vitti; Voza (2011, p. 318); Lo Sardo (1999, p. 94).

${ }^{13}$ Cf. Sibari V. p. 304; cf Belvedere, 1986, p. 12, which gives to stenopos AB2, we do not know why, the value of 4,30 m. 
According to the reported measures of stenopos ABl, of which we possess evidences only in the south margin of plateia B, the N-S stenopos would have had twice the width of E-W stenopoi. Once more another mathematical ratio of 1:2. In a nutshell, our argument is that beginning the alignment of the first block in the demarcation offered by the crossroad of the orthogonal plateiai A and B previous defined in Parco del Cavallo, the geometer would proceeded in the scansion of the blocks in two directions, to the north and to the east. Instead of measuring the block's dimensions by its margins in front of the major roads and by its margins bordering stenopoi N-S and E-W, as in Selinious and in Halieis, it was done taking both axial lines of the stenopoi, marking as departure point always the margin offered by the space due to the plateiai (fig. 8).

Figure 8 - Urban scansion in Thurioi according to our working interpretative framework. Drawing: authors.

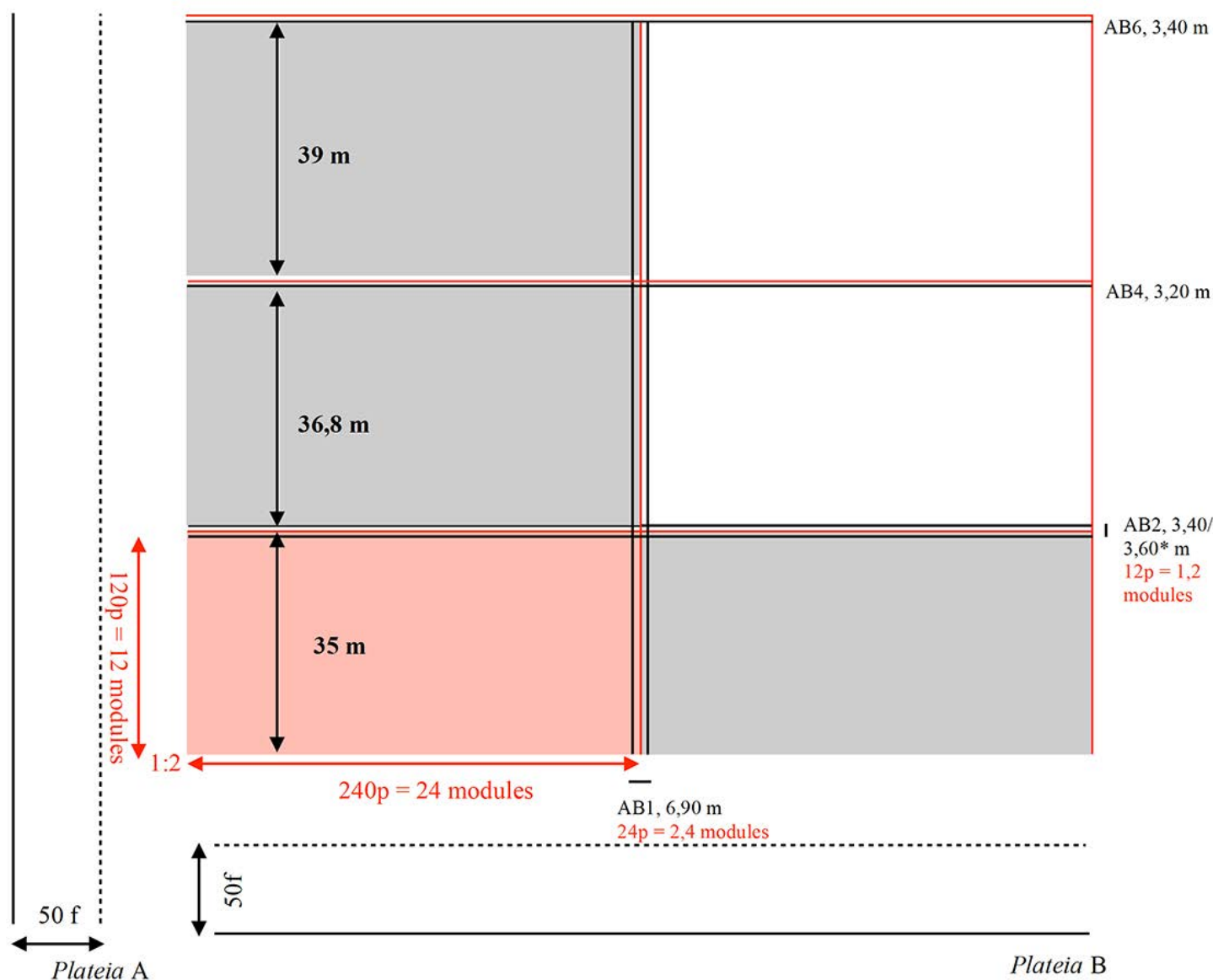


Carrying a knotted rope or an alignment chain inscribed with the module value the geometer took two vectors, gesture too similar to the shape of a square, the measurement tool constituted by two bars in straight angle used extensively by the Greeks in woodworking and masonry craft (Ginouvès; Martin, 1985, p. 76). In the unfolding of the planning the geometer could demarcated each block by its central axis and these lines also aligned the central axis of the parallel and perpendicular stenopoi (ABl and AB2, for instance). On the other hand, these axes also offered the two margins to the next round of block scansion.

To conclude this section, it is revealing to note among several texts written by Greco on Greek history and urbanism, countless on Thourioi's planning, we find only in his novel Il mantello della Sosandra... come un ateniese apprese la storia della fine di Sibari [The mantle of Sosandra... as an Athenian had learned the story of the end of Sybaris] (2011), published by a small Roman publishing house, a singular description of the work of a land surveyor in ancient Greece. In the fiction novel, the land measurement is done in the rural area of the Esaro river valley, between Sybaris and Crotone, at the command of the assembly convened by the tyrant Telys. To achieve this, a Tarantian geometer

[...] aveva tracciato un lungo asse che seguiva il corso del fiume, scavalcandolo quando le anse lo rendevano necessario, ed una serie di stradine perpendicolari che salivano fino ai rilevi collinari più bassi [...]; agli incroci, [...] gli oristi avrebbero collocato dei cippi di pietra tenera, senza nome, in attesa di segnarvi quello del proprietario, mentre lungo i margini delle strade, sia la grande che le minori, sarebbero stati collocati i cippi con l'iscrizione: 'strada della polis' (Greco, 2011, p. 49-50). ${ }^{14}$

Non-specialist readers have to keep in mind behind the literary imagination of the passage lays a vast professional experience of the author..$^{15}$ The freedom afforded by the literary style also gives us a glimpse of how simple the process of orthogonal planning could be. Despite the complicate numerical relations which fill our tables, as an ensemble it constitutes a style, definied by the art anthropologist Alfred Gell (1998, p. 215) as a "[...] 'relation between relations' of forms". Is not Thourioi also part of an ancient tradition of making orthogonal cities? A method of demarcation of lots in the territory in a patterned way?

14 "[...] had drawn a long axis that followed the course of the river, getting across it when the meanders made it necessary, and a series of perpendicular lanes that climbed up to the lower hills [...]; at the crossings, [...] the orists would have placed some soft markers, nameless, waiting to demarcate the owner's name, while along the margins of the roads, both majors and minors, markers would have been placed with the inscription: 'road of the polis'.

${ }^{15}$ Another passage of the novel has inspired the production of a digital mockup of Thurioi, an educative resource made available online in the website of the Labeca (cf. Florenzano et al., 2015). 


\section{A physical trait of urban measurement}

Looking at the order of Thurioi's planning, in some way we go back to the beginning of this paper, which is to say the demarcation of major roads. Not for nothing have scholars thought so after Diodurus' description (Cahill, 2002, p. 22) and we subscribe to this opinion as long it not obliterates the multilayered process of planning and the interdependence of its component parts. We suggest here that this procedure is materialized by a technical feature related to the construction of these roads. Plentiful archaeological evidence supports the identification of one expedient to align the axis of the major roads. In Sibari IV (p. 184), a central stripe made of hewed stones running in the axial line of the N-S plateia (A) is described. This strip runs together with transversal, and more irregular, strips which run from the eastern to the western's sewer (Figure 9). What are the purposes of this kind of alignment?

Figure 9 - Plateia A, photo taken from the north side. Detail of hewn stones aligned in the median axis of the road. Source: Sibari IV (p. 185, Fig. 179).

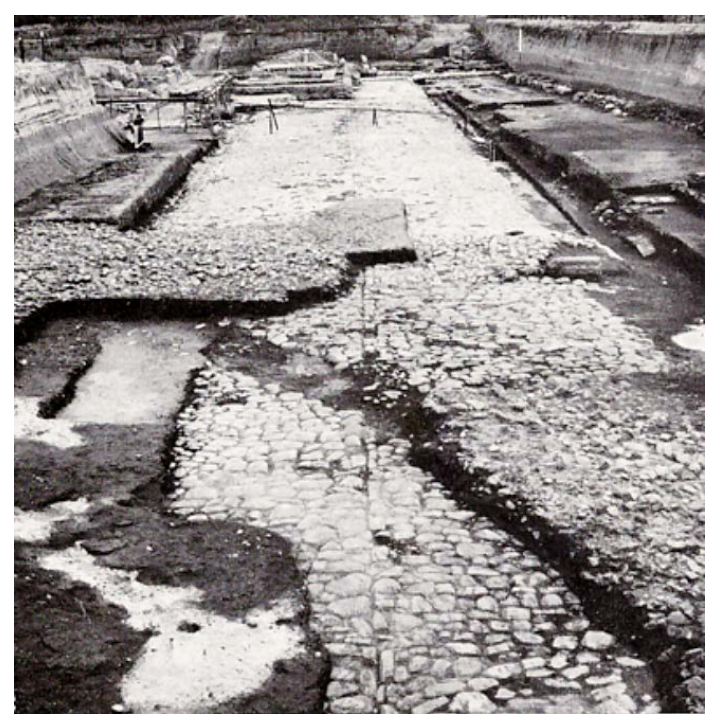

Guzzo has argued when reporting this finding that this kind of procedure could establish both the outline of the road (in Italian, dosso d'assino [back of a donkey], like an inverted V) and its slope towards the north (part of an overall and variegated drainage system in Thourioi). ${ }^{16}$ This feature has not been identified in the southern trait of the road

${ }^{16}$ More precise information about Thurioi's drainage system we were able to collect concerning the sloping of Thurioi's road network, besides plateia A, relates to the east-to-west sloping of the stenopoi AB2, AB4, and AB6 (cf. Sibari V, p. 302). 
reported in previous publications (Sibari III, p. $265 \mathrm{sgg}$.). One of the reasons for this may be the modification of the pavement by the Roman buildings constructed on the northwest sector of that road (Sibari IV, p. 184; 189). ${ }^{17}$ Plateia B, which lead to the port installations in Casa Bianca with only a slightly angular deviance after crossing orthogonally plateia $A$ and plateia $\mathrm{C}$, has sewers and an outline that change along its way, being even unpaved in its final trait. At Parco del Cavallo, east from the crossing with plateia A, plateia B's outline is the same as of that road. Westward, there is only one central sewer and a section in V profile. The change could be attributed to the successive modifications that the semi-circular Roman building caused at the first century AD, as well as the many restorations suffered over the years (Sibari II, p. 490-493). Thus, to search in this section of the road the same alignment mentioned above could be a fruitless effort. However, the strip also occurs in Prolungamento Strada. In the western side of this archaeological area, there is a lacunar central strip of hewed stones with outflow system of two lateral sewers (Sibari IV, p. 303). We can see, then that when the plateiai have not a dorso d'asino profile, they are constructed from the axis offered by the central sewer (i.e., in $\mathrm{V}$ profile). ${ }^{18}$

We believe that going through [In] small things forgotten, to paraphrase Deetz's ([1977] 1996) famous book title, is a very valuable step to acquire a renewed perception of how the town's planning techniques worked in the past. We recognize that our interpretation of the empirical data is in variance with what was previously said about the ideal reconstruction of an urban plan grounded on the excavation of a sampled area. It must be reinforced, therefore, that "Users of standard works on ancient city planning should be warned that actual-state plans of cities may differ considerably from familiar reconstructed plans, often based on very little excavation" (Boyd; Jameson, 1981, p. 338). We hope to make it clear this is not a convenient excuse and we do not exempt ourselves from doing

\footnotetext{
That means that the drainage system will empty the water into the eastern sewer of plateia A, then it will flow towards the south and, depending on the slope of plateia B, probably to the east, towards the coast. In addition, plateia C slopes from north to south, a feature that also characterizes the flow of water into the plateia B (Sibari V. p. 336). Taken together, these evidences combined with the pieces of information regarding the changing outline of the roads reveal an organization cut-crossing this intricate pattern. Its underlying logic is to avoid overwhelming the drainage system by flowing the water from the N-S plateiai into the same E-W plateiai, channeling the flowing water in different paths instead.

${ }^{17}$ Cf. Sibari Il, p. 437 on the roadway outline; also, Guzzo (1973, p. 294-295). It may be noted, however, Guzzo made a small mistake by saying that the road has a central sewer and $a \mathrm{~V}$ section covered by beaten earth, as we can correct not only reading the archeological reports, as well the page 291 of the same article.

${ }^{18}$ The evidence of the simultaneous use of both systems, as in N-S plateia E, in Casa Bianca, presents some trouble to this argument. However, we believe that there is also a small trouble as far as the accuracy of information on the arterial road is concerned. As a matter of fact, plateia E seems to have been built with a profile of an inverted $V$ with an outflow sewer that served also as its median axis (Sibari 2007; 2009-2012, p. 113). This road was identified east of the sanctuary structure (building $N$ ) that had restricted it in the first century AD to almost half of its original width, near to its crossing with plateia B. We question the accuracy of that information because in a photo taken of the excavated area plateia E seems (but we are not sure of this because we could not check it elsewhere) that its profile is not in dorso d'asino, as informed, but in concave format (amplification 1-2, west from structure N; cf. Sibari 2007; 2009-2012, p. 116, Fig. 132).
} 
exactly that. We used these reconstructions and think that they are a reliable sort of graphical laboratory where we can test some hypotheses and make of it a useful tool to select the next archaeological area to be explored. After the extensive works of 1970s, the choice of smaller areas had to be defined in archaeological program's goals and the idea of a schematic and regular plan predictable from the previous results proved successful (Greco; Luppino, 1999).

Observing Figure 8 (see also table 3) attentively, it is possible to predict an apparent contradiction which can become more acute if archaeological works proceed. It seems that simple measures do not fit rigid schemes for too long. Considering the northern border of the plateia B, and proceeding from south to north, the width of blocks increases: 35, 36,80 e $39 \mathrm{~m}$, respectively. ${ }^{19}$ Moreover, the width of E-W stenopoi right and left of plateia A differ, even if small. How can we explain the increasing metric differences of the blocks as long we go to the north? What this means in technical terms of planning? Ferdinando Castagnoli (1973, p. 222, note 4) already emphasized that Thourioi was a typical per strigas plan (according to the Latin term) with perpendicular blocks to the coast that had been measured from south going north. Although his argument concerning the existence of stenopoi only in the E-W direction, forming long rectangular blocks, is outdated, we keep this idea of the scansion direction.

The data regarding the width of the road that closes the northern side of the rectangle (plateiai D) presents another problem. Dividing the horizontal side into 10 parallel blocks (including $8 \mathrm{E}-\mathrm{W}$ stenopoi in a parallel series) and the vertical side into 4 blocks (and $3 \mathrm{~N}$-S stenopoi), it would imply a necessary contraction in the space available to fit northern blocks not yet excavated. Or maybe should we consider a subtraction of some of them (why not)? Taking into account that the distance N-S from plateia B to the margin south of plateia D is 1200 feet long, we would have 120 feet, at least ideally, to each block and its respective stenopoi in one of its margins. In the first block plus stenopos AB2, we would obtain the value close to 120 feet (124 feet, $36,8 \mathrm{~m}$, counting the width of the block of 112 feet and the width of 12 feet of the stenopos). However, as we have already seen, this measure increases in the next blocks to the north (40 and 42,4 $\mathrm{m}$, for the second and third blocks plus stenopoi AB4 and AB6, respectively). In the E-W direction, the space of 930 feet from the eastern margin of plateia A to the western margin of plateia C defines 232,5 feet for each block and its corresponding N-S stenopoi. That means that the eastern blocks, still buried there, would be contracted. Are we thus in a logical impasse?

${ }^{19}$ Determining the distance, for the first block, from the northern border of plateia B to the axis of AB2 (cf. Sibari III, p. 269; 444). For the second block, the distance from the axis of AB2 to the margin north of a stone that was placed to interrupt the traffic of cars and, finally, for the third block, the distance from the margin north of this stone to the southern margin of another stone to the north (cf. Sibari V. p. 302). 


\section{"The stillness, as a Chinese jar still / Moves perpetually in its stillness" (Eliot, 1968, Burnt Norton, v. 142-143)}

How to explain all these metrical differences? The first point to make here is that no town planning follows strictly the exact composition as in musical notation. Contrastively to the last, as well as to other artistic works as literature and architecture, town planning does no encase itself in tight spatio-temporal limits. Cities are far from being a finished work made as image and likeness of an abstract design. And even if we can extend the argument and say that Archaic and Classical Greek urbanism has not need of graphical plans or visual aids (Peixoto, 2017), which is not our intention to do in this paper, at the end, in planning

Only partial control can be exercised over its growth and form. There is no final result, only a continuous succession of phases. No wonder, then, that the art of shaping cities for sensuous enjoyement is an art quite separate from architecture or music or literature. It may learn a great deal from these other arts, but it cannot imitate them (Lynch, 1960, p. 2).

It is important to keep into account even in schematic representation of Thourioi's urban grid, metrical differences are expected and, indeed, a great deal of them arisen along the process of urban implementation. The environment played an important role to shape the very urban form of the city. In Thurioi, historical contingencies related to the suitability of the soil for building public structures as the major paved roads had to be taken in consideration by the planner. Recent excavations in an area near the Roman gate (Porta Nord, fig. 3), situated over plateia D, and whose wall encircles part of the Classical city, showed that plateia A juxtaposed an older Archaic N-S axis (cf. Greco; Luppino, 1999, p. 138-140; 153; Greco, 2003, p. 371-372; Greco, 2014, p. 5). Probably this Archaic alignment was made over an ancient crest of sandy dune which makes the marshy soil more suitable to support a physical structure (cf. Greco, 2003, p. 372; Guzzo, 2016. p. 30).

Nowadays, researchers are more and more prone to consider both geomorphological and historical factors like drainage of the soil and previous human occupations of the site before they start talking about plan reconstruction. In fact, "In the study of the past there is a tendency to pass favourable judgement upon examples of striking layout, often possessing a marked degree of regularity, and to seek an edifying rationale" (Kemp, 2000, p. 336). Thourioi's urban planning could not be an ex novo plan originally programmed to search a startling degree of rationality as someone's ideal city.

In this regard, therefore, the kind of "metrical dissonances" pointed out in the previous section speaks volumes about a planning of which was once said that a "[...] ricerca quasi 
maniacale delle simmetrie e del rapporto tra le singole parti e il tutto [...]"20 (Greco, 1999, p. 425) was performed. On the one hand, it seems to us that the high schematic structure observed in Thourioi could explain its symbolic malleability to plan reconstructions. On the other hand, this same rigid frame created by the 4 plateiai fixes a limit that cannot be altered. It is not malleable. And this is a new feature employed in the orthogonal planning from the sixth century BC in the city of Selinous, in Sicily, Halieis, in Argolid, and in the Athenian port, Piraeus (Di Vita, 1996; Boyd; Jameson, 1981; Belvedere, 1986).

The salient feature of Thourioi's plan has to be searched both in its close bonding of elements - already recognized by ancient urbanism students as a symbol of a highly rational project - and in the pragmatic constraints imposed by the physical environment, its incalculable nature which will continue to be exhumed as long as archaeologists keep digging deeper and deeper. We can begin listing, for instance, the marshy soil and groundwater table which always cause considerable difficulties to archaeologists going down. Or the angular variation of $25^{\mathrm{o}}$ degrees, regarding the roadway network of Parco del Cavallo, of one unpaved road that has been recently excavated (in Lattughelle) and that could, or not, be plateia F. Last but not least, magnetic surveys conducted in September 2009 have revealed a ditch of wall $120 \mathrm{~m}$ north of plateia $\mathrm{D}$ of what could be the Classical fortification and that turns the picture all the more complicated. Would that ditch be a part of the urban planning located outside the walls? (cf. Greco; Luppino et al., 2003, p. 107; Greco; Vitti; Voza, 2011, p. 317).

Thourioi's planning reveals a set of recurring features that tie it up in a bundle of Greek customs related to land measurement. It makes the tradition of orthogonal technique a crystallized modus operandi of territorial planning, the product of a dialectic interplay between custom conditioned by practice and material engagement in a specific cultural milieu (Bourdieu's habitus, [1972] 2000, p. 393, note 39). These techniques created through its recipes of making cities physically experienced forms, built environments that also had resonance in cultural identity in the meanings they bear (Rapoport, 1982, p. 15). The form of the city is the mold where cultural identity is cast in (Malaco, 2002, p. 46). The marked degree of regularity observed in the orthogonal system also discloses a marked degree of group identity built by material culture. By this we imply a "heraldic" statement about cultural affiliations shared by colonists vis-à-vis indigenous communities putted out by Greek planners, the "prototypical human connectors," in Malkin's (201l, p. 28) words, of the maritime network that connects goods and people along great stretches of the Mediterranean basin (Malkin, 2003, p. 59; cf. 2011, p. 5; 54).

Thus, when we look at the contact zone between Greek migrants and indigenous populations in south Italy and Sicily, these material traits of cultural distinction became

20 "[... almost a maniacal research of symmetries and relationship between the single parts and the whole [...]". 
even more marked. In the urban fabric on the frontier Western Greek foundations there is a need to produce social cohesion and organization (Florenzano, 2009, p. 95). But here we are also discussing both identities created through regularity of practice which individuals, in the past or in the present, may and may not be aware of. Material culture encompasses all dimensions of living and we archaeologists can distinguish some meaningful patterns in it (Antonaccio, 2001; 2009). Antonaccio (2009, p. 38) has brilliantly captured the ubiquity of the human encounters with material culture, stating

Experience encompasses the built environment in a recursive relationship; material culture makes us as much as we make things. Moreover, material culture includes knowing how something functions, how it is used, and what to use it with. This can be tested by observing the recurring patterns of material culture associated with the contexts in which objects are found - and also by observing when there are divergences from a pattern.

Summing up our argument, the arithmetical sequence of 1:2 ratio between width/ number of lots in the N-S direction and between width/length of blocks is a very common pattern in Greek orthogonal planning. This type of formulaic pattern was extensively discussed in Peixoto's (2017) M.A. dissertation (Técnica urbana ortogonal e teoria da poesia oral [Orthogonal technique and oral poetry theory: from Megara Hyblaea to Thourioi]; see also Peixoto, 2019), which also presents an overview of current state of research on orthogonal layouts of overseas Greek foundations, notably Thurioi's. ${ }^{21}$ We do not have enough space here to expand on this, so we can state briefly that this is a kind of pattern that we archaeologists are able to identify in the long run of our chronologies. Hurwit (1985) has already drawn a striking parallel between the system of oral formula of Homeric poetry and the visual formulas of the geometric vase paintings of the iconic Dipylon Master. Hurwit (1985, p. 97) writes:

In both, the formula - not the single word, not the single brush stroke - is the basic compositional unit. The poet [...] is as much a builder of narrative surfaces as the vase painter is of decorative surfaces (and tektōn epeōn, 'builder of words,' is just how the Greek could conceive of their poets).

\footnotetext{
${ }^{21}$ For up-to-date interpretations or new report of findings during the previous decade in Sibari/Thurioi, we highlight Sibari 2007; 2009-2012; Greco; Vitti; Voza (2011), commenting the last five years of archaeological work in Casa Bianca; Caliò (2012, p. 105-126), with major focus on political philosophy underlying Classical urban planning; Greco (2014), and references therein; and Guzzo (2016), a publication derived from archaeological interventions carried out in 2014 for the building of a new hydraulic pumping system in the site.
} 
We see another parallel in the formulas of town planning. And this metaphorical relationship with oral composition could be strengthened if we recognize, in line with Lynch (1960, p. 1), that both are temporal arts. As intuitively T.S. Eliot (1968, Burnt Norton, V, v. 137-149) perceived in his poetical thought:

\author{
Words move, music moves \\ Only in time; but that which is only living \\ Can only die. Words, after speech, reach \\ Into the silence. Only by the form, the pattern, \\ Can words or music reach \\ The stillness, as a Chinese jar still \\ Moves perpetually in its stillness. \\ Not the stillness of the violin, while the note lasts, \\ Not that only, but the co-existence, \\ Or say that the end precedes the beginning, \\ And the end and the beginning were always there \\ Before the beginning and after the end. \\ And all is always now.
}

These very same verses are quoted in the epilogue of Gombrich's The sense of order (1984, p. 285). And we think it is fair to bring these non-archaeologist writers to the fore, literary sources of inspiration due to the fact that they insightfully perceived things that competent archaeological theoreticians many times did not. ${ }^{22}$ As exception to this statement, we can remember the instigating studies of the Norwegian archaeologist Bjørnar Olsen (2010) takes in his In defense of things (2013). Journey through chapters dealing with theoretical stuff, the author remembers of literature and philosophical writers like Jorge Luis Borges, Marcel Proust, Henri Bergson and Walter Benjamin, etc., to make the case of the materialness of things, the material stuff of ordinary experience, and their active role in human engagement both to existence and to the constitution of habitual memories (Olsen, 2010, p. 61, 120). The great merit of approach like this is to produce an original reflection on the autonomy of the stock-in-trade of archaeology in face of the social sciences and philosophy, which for a long time have sidestepped this vital ingredient of social life (Olsen, 2010, p. 2); as well as to reveal "[...] things faithfully remember also the ineffable and those forgotten 'in talkative history', giving face to the ordinary and the leftover" (Andreassen; Bjerck; Olsen, 2010, p. 16).

All things considered, in Thourioi we have an urban scheme calling forth an old ratio well

${ }^{22}$ Cf. however Hodder (2012, p. 121-122), who discuss Gombrich's work. 
known in Greek orthogonal planning. Its formulas stretch in time as resources long applied in the history of ancient planning. In our case, these formulas of an old urban system are bond together in a new pattern, as the formular repertoire of verse-making have been proved to be to oral composition after the ideas of Parry (1971) and Lord (1991; 2000) drew on their own ethnographic fieldwork with Yugoslavian singers in the earlier 19th century. New patterns resemble old ones and new formulas are created, both in Homeric hexameter composition and orthogonal urban technique, within the metrical space of "long-proven" formulas (Parry, 1971, p. 332). The mastery of these patterns can be considered as an ancient tune played by the crafter's "skilled movement" (Ingold, 2000, p. 342, author's italics) and “[...] we respond to shapes much as we respond to music by dancing inwardly" (Gombrich, 1984, p. 201).

The Gulliverian metaphor represents an urban technique similar in many regards to previous ones, but still quite new. As a matter of fact, the orthogonal pattern found in Thourioi invites us to learn more about the technical procedures, the measurement instruments and the materiality mobilized when doing these things on the ground. In short, to appreciate the work of the seamstress of its urban fabric. All these are pragmatic and archaeological questions about what these built environments were made of, how they were made, what equipment and tools were used (Hodder, 2012, p. 30). This is the movement of the still forms, the stillness of speechless row of stones of Greek orthogonal cities.

\section{Bibliography}

\section{Abbreviations}

AttiMemorie 1974 = AA.VV. Atti e Memorie della Società Magna Grecia. Nuova Serie XIII-XIV (1972-1973). Roma: Società Magna Grecia, 1974.

Sibari II = AA.VV. Sibari II. Scavi al Parco del Cavallo (1960-1962, 1969-1970) e agli Stombi (1969-1970). NSA [Notizie degli scavi di antichità], Supp. III. 1970.

Sibari III = AA.VV. Sibari II. Rapporto preliminare della campagna di scavo: Stombi; Casa Bianca; Parco del Cavallo; San Mauro (1971). NSA, Suppl. 1972

Sibari IV = AA.VV. Sibari IV. Relazione preliminare della campagna di scavo: Stombi, Parco del Cavallo, Prolungamento Strada, Casa Bianca (1972). NSA, Suppl. 1974.

Sibari V = AA.VV. Sibari V. Relazione preliminare delle campagne di scavo 1973 (Parco del Cavallo, Casa Bianca) e 1974 (Stombi; Incrocio; Parco del Ca- vallo; Prolungamento Strada; Casa Bianca). NSA, Supp. III. 1988-1989.

Sibari2004 = AA.VV. Sibari 2004. ASAA [Annuario della Scuola archeologica di Atene], v. LXXXII, s. III, 4, t. II, p. 823-840. 2004.

Sibari 2005 = AA.VV. Sibari 2005. ASAA, v. LXXXIII, s. III, 5, t. II, p. 1001-1066. 2005.

Sibari 2006 = AA.VV. Sibari 2006. ASAA, v. LXXXIV, s. III, 6, t. II, p. 1025-1094. 2006.

Sibari 2007; 2009-2012 = AA.VV. Il santuario delle divinità orientali e i suoi predecessori (Sibari-Casa Bianca): scavi 2007, 2009-2012. ASAA, v. LXXXIX, s. III, 1l, t. II. 2011.

\section{References}

ANDREASSEN, Elin; BJERCK, Hein B; OLSEN, Bjørnar. Persistent memories: Pyramiden: a Soviet mining town in the High Arctic. Trondheim: Tapir, 2010. 
ANTONACCIO, Carla M. Ethnicity and colonization. In: MALKIN, Irad. (Ed.). Ancient perceptions of Greek ethnicity. Cambridge, MA: Harvard University Press, 2001.

ANTONACCIO, Carla M. (Re)defining ethnicity: culture, material culture, and identity. In: HALES, Shelley; HODOS, Tamar. (Eds.). Material culture and social identities in the Ancient World. Cambridge, NY: Cambridge University Press, 2009, p. 32-53.

BELVEDERE, Oscar. Himera, Naxos, Camarina, tre casi di urbanistica coloniale. Xenia, v. 14, p. 5-20, 1986.

BOURDIEU, Pierre. Esquisse d'une théorie de la pratique. Paris : Éditions du Seuil, 2000.

BOYD, Thomas. D.; JAMESON, Michel. H. Urban and rural land division in ancient Greece. Hesperia, v. 50, p. 327-342, 1981.

CAHILL, Nicholas. Household and city organization at Olynthus. New Haven/London: Yale University Press, 2002.

CALIÒ, Luigi M. Asty. Studi sulla città greca. Roma: Edizioni Quasar, Thiasos Monografie, 2, 2012.

CASTAGNOLI, Ferdinando. Ancora sull'urbanistica di Thurii. La Parola del Passato, v. 150, p. 220-222, 1973.

CERCHIAI, Luca; JANNELLI, Lorena; LONGO, Fausto. The Greek cities of Magna Graecia and Sicily. Los Angeles: J. Paul Getty Museum, 2004.

DEETZ, James. In small things forgotten: the archaeology of early American life. New York: Anchor Press, 2nd ed., 1996.

DI VITA, Antonino. L'urbanistica. In: AA.VV. Sikanie. Storia e civiltà della Sicilia greca. Milano: Garzanti, III ed., p. 357-414, 1989.

DIODORUS SICULUS. Library of history, volume IV: books 9-12.40. Translated by C.H. Oldfather. Cambridge, MA: Harvard University Press, 1946.

ELIOT, Thomas S. Four quartets. New York: Houghton Mifflin Harcourt, 1968.

FLORENZANO, Maria Beatriz B. A contribuição das colônias ocidentais na construção da identidade políade: subsídios do uso e da organização do espaço. In: FLORENZANO, Maria Beatriz B. ; HIRATA, Elaine Faria V. (Eds.). Estudos sobre a cidade antiga. São Paulo: EdUSP, 2009, p. 93-108.
FLORENZANO, Maria Beatriz B. O espaço ordenado na cidade grega antiga: lotes, quarteirões ou eixos viários? In: LIMA, Alexandre Carneiro C. (Ed.). Imagem, gênero e espaço: representações da antiguidade. Niterói: Alternativa, 2014, p. 87-97.

FLORENZANO, Maria Beatriz B. et al. Uma cidade grega, 2015 (digital mockup). Available at: 〈http:// labeca.mae.usp.br/pt-br/professores/maquetes-digitais/>. Accessed 2 May 2020.

GELL, Alfred. Art and agency: an anthropological theory. Oxford, NY: Clarendon Press, 1998.

GINOUVÈS, René; MARTIN, Roland. Dictionnaire méthodique de l'architecture grecque et romaine. Tome 1. Matériaux, techniques de construction, techniques et formes $d u$ décor. Rome/Athènes: École française de Rome/École française d'Athènes, 1985.

GOMBRICH, Ernest H. The sense of order: a study in the psychology of decorative art. New York: Phaeton Press, 2nd edition, 1984.

GRECO, Emanuele. Turi. In: GRECO, Emanuele. (Ed.). La città greca antica: istituzioni, società e forme urbane. Roma: Donzelli, 1999, p. 413-430.

GRECO, Emanuele. The urban plan of Thourioi: literary sources and archaeological evidence for a Hippodamian city. In: OWEN, Sara; PRESTON, Laura. (Eds.). Inside the city in the Greek world: studies of urbanism from the Bronze Age to the Hellenistic period. Oxford, UK: Oxbow Books, 2009, p. 108-117.

GRECO, Emanuele. Il mantello della Sosandra... come un ateniese apprese la storia della fine di Sibari. Roma: Edizioni Tored, 2011.

GRECO, Emanuele. Sullo इXHMA di Thurii: venti anni di ricerche. Annuario della Scuola Archeologica di Atena e delle Missioni Italiane in Oriente, v. XCII, s. III, 14, p. 1-11, 2014.

GRECO, Emanuele; LUPPINO, Silvana. Ricerche sulla topografia e sull'urbanistica di Sibari-Thuri-Copiae. In: Annali di Archeologia e Storia Antica, n. 6, p. 115-164, 1999.

GRECO, Emanuele; LUPPINO, Silvana et al. Alla ricerca di Ippodamo di Mileto. L'impianto urbanistico di Thurii. La campagna di scavo 2003 a Sibari in località Lattughelle. Polis: studi interdisciplinari sul mondo antico, v. III, p. 97-116, 2003. 
GRECO, Emanuele; VITTI, Paolo; VOZA, Ottavia. Appunti sulla topografia di Casa Bianca. Sibari 2007; 2009-2012, p. 305-319, 2011.

GUZZO, Pier G. Scavi a Sibari. Parola del Passato, v. 28, p. 278-31, 1973.

GUZZO, Pier G. I risultati degli scavi. AttiMemorie 1974 , p. 35-45, 1974.

GUZZO, Pier G. Scavi a Sibari 2. Annali di Archaeologiae Storia Antica, v. 3, p. 15-27, 1981

GUZZO, Pier G. Speciale Sibari. Forma Urbis, v. XXI, p. 26-35, 2016.

HODDER, Ian. Entangled: an archaeology of the relationships between humans and things. Oxford, UK: Willey-Blackwell, 2012.

HURWIT, Jeffrey M. The art and culture of early Greece, 1100-480 B.C. Ithaca, NW/London: Cornell University Press, 1985.INGOLD, Tim. The perception of the environment: essays on livelihood, dwelling and skill. London/ New York: Routledge, 2000.

KEMP, Barry. Bricks and metaphor. Cambridge Archaeological Journal, v. 10, n. 2, p. 335-346, 2000.

LYNCH, Kevin. The image of the city. Cambridge, MA: The Technology Press/Harvard University Press, 1960.

LO SARDO, Piero. Verso il canone della polis. In: GRECO, Emanuele. (Ed.). La città greca antica. Istituzioni, società e forme urbane. Roma: Donzelli Editore, 1999, p. 83-97.

LORD, Albert B. Epic singers and oral tradition. New York: Cornell University Press, 1991.

LORD, Albert B. The singer of tales. Cambridge, MA: Harvard University Press, 2nd ed., 2000.

MALACO, Jonas T.S. Da forma urbana: o casario de Atenas. São Paulo: Alice Foz, 2002.

MALKIN, Irad. Networks and the emergence of Greek identity. Mediterranean Historic Review, v. 18, n. 2, p. 56-74, 2003.

MALKIN, Irad. Introduction: networks and history. In: MALKIN, Irad. A small Greek world: networks in the ancient Mediterranean. Oxford, NY: Oxford University Press, 2011.

OLSEN, Bjørnar. In defense of things: archaeology and the ontology of objects. Lanham: AltaMira Press, 2010.
PARRY, Milman. The making of Homeric verse: the collected papers of Milman Parry. Oxford, NY: Clarendon Press, 1971.

PEIXOTO, Renan F. Técnica urbana ortogonal e teoria da poesia oral: de Mégara Hibleia a Túrio. Dissertação (Mestrado em Arqueologia), Universidade de São Paulo. São Paulo, 2017.

PEIXOTO, Renan F. Poesia oral e tradição urbanística ortogonal: intersecções teóricas. In: PORTO, Vagner C. (Ed.). Arqueologia hoje: tendências e debates. São Paulo: MAE/USP, 2019, p. 597-613.

PEREC, Georges. Life: a user's manual. Translated by David Bellos. London: Vintage, 2008.

RAPOPORT, Amos. The meaning of the building environment: a nonverbal communication approach. Tucson: University of Arizona Press, 1982

SHIPLEY, Graham. Little boxes on the hillside: Greek town planning, Hippodamos, and polis ideology. In: HANSEN, Mogens H. (Ed.). The imaginary polis. Acts of the Copenhagen Polis Centre vol. 7. Copenhagen: Royal Danish Academy of Sciences and Letters, 2005, p. 335-403.

SMITH, Michael E. Form and meaning in the earliest cities: new approach to ancient urban planning. Journal of Planning History, v. 6, n. 1, p. 3-47, 2007.

SVENBRO, Jesper. À Megara Hyblaea : le corps géomètre. Annales. Économies, Societés, Civilisations, v. 37, n. 5-6, p. 953-964, 1982.

SWIFT, Jonathan. Gulliver's travels. London: Collector's Library, 2004.

TRÉZINY, Henri. Lots et îlots à Mégara Hyblaea. Questions de métrologie. AA.VV. La colonisation grecque en Méditerranée occidentale. Actes de la rencontre scientifique en hommage à Georges Vallet organisée par le Centre Jean-Bérard, l'École française de Rome, L'Istituto universitario orientale et l'Università degli studi di Napoli « Federico II » (Rome-Naples, 15-18 novembre 1995). Roma: École Française de Rome, 1999, p. 141-183.

WILSON JONES, Mark. Doric measure and architectural design 2: a modular reading of the Classical temple. American Journal of Archaeology, v. 105, 2001, p. 675-713. 